\title{
Why Not a Global Currency?
}

\section{Citation}

Rogoff, Kenneth. 2001. Why not a global currency? American Economic Review 91, no. 2:

243-247.

\section{Published Version}

doi:10.1257/aer.91.2.243

\section{Permanent link}

http://nrs.harvard.edu/urn-3:HUL.InstRepos:11129183

\section{Terms of Use}

This article was downloaded from Harvard University's DASH repository, and is made available under the terms and conditions applicable to Other Posted Material, as set forth at http:// nrs.harvard.edu/urn-3:HUL.InstRepos:dash.current.terms-of-use\#LAA

\section{Share Your Story}

The Harvard community has made this article openly available.

Please share how this access benefits you. Submit a story.

Accessibility 


\title{
Why Not a Global Currency?
}

\author{
By KenNeth RogofF*
}

It appears likely that the number of currencies in the world, having proliferated along with the number of countries over the past 50 years, will decline sharply over the next two decades. The question I plan to pose here is: where, from an economic point of view, should we aim for this process to stop? Should there be a single world currency, as Richard Cooper (1984) boldly envisioned? Should there remain multiple major currencies but with a much stricter arrangement among them for stabilizing exchange rates, as say Ronald McKinnon (1984) or John Williamson (1993) recommended? ${ }^{1}$ Building on Maurice Obstfeld and Rogoff (2000b, d), I will argue here that the status quo arrangement among the dollar, yen, and euro (which I take to be benign neglect) is not far from optimal, not only for now but well into the new century. And it would remain a good system even if political obstacles to achieving greater monetary policy coordination (or even a common world currency) could be overcome. Again, this is not a paper on, say, the pros and cons of dollarization for small and medium-sized economies, but rather on arrangements among the core currencies.

Any blueprint for the future core of the world currency system involves some crystal-ball gazing. But at the same time, recent research in international macroeconomics offers several important insights that can help inform the discussion.

\section{The Exchange-Rate Disconnect Puzzle}

The typical assessment of the modern floatingrate era begins by noting just how wrong Milton Friedman (1953) was when he envisioned flex-

\footnotetext{
* Economics Department, Littauer Center, Harvard University, Cambridge MA 02138-3001 (e-mail: Krogoff@ harvard.edu). I am grateful to Philip Lane and Doireann Fitzgerald for very helpful comments, and to the National Science Foundation for research support.

${ }^{1}$ For a recent survey of G-3 exchange-rate stabilization plans, see Richard Clarida (2000).
}

ible exchange rates as adjusting slowly and smoothly in response to differentials in relative national price levels. Nothing could be further from the truth, and as virtually everyone knows by now, exchange rates fluctuate wildly in comparison with goods prices. Early in the flexiblerate experience, theorists offered what appeared to be an attractive answer to this observation: currency is a durable, so fundamentally its price reflects a flow of future services, not simply its transactions value at a point in time. Thus, according to the "asset" view of exchange rates, it should be no surprise that they fluctuate almost as wildly as stock prices.

Although the stock price analogy is useful, it is far from perfect. Given that domestic goods prices tend to move very sluggishly, at least at the consumer level, one would think that goodsmarket arbitrage would prevent the exchange rate from fluctuating like a typical major stock price index-but, of course, it does. At the aggregate level, shocks to real exchange rates damp out at a remarkably slow rate. Even the most optimistic estimates put the half-life of real exchange-rate movements in years, not months (though as Obstfeld and Rogoff [2000a] demonstrate, a country's terms of trade at the wholesale level seem to react much faster than at the consumer level). The "purchasing-powerparity puzzle" is but one manifestation of a broader range of puzzles which Obstfeld and Rogoff (2000b) call "the exchange-rate disconnect puzzle." Simply put, while the exchange rate seems to gyrate wildly, it does not appear to feed back into the real economy with nearly the force and speed that one would expect for such an important relative price. (Again, remember that my focus is on cross-country exchange rates between the largest economies.) Marianne Baxter and Alan Stockman (1989), in their comparison of macroeconomic variables under fixed and flexible exchange-rate regimes, first pointed out the difficulty in demonstrating that exchangerate volatility affects macroeconomic quantities. Though more recent research has succeeded in showing that exchange-rate volatility can impact 
trade and direct foreign investment, ${ }^{2}$ overall the feedback to the real economy is far slower and less pronounced than canonical Mundell-Fleming models would predict. Some have gone so far as to interpret the evidence as showing that exchange rates have no short-run expenditureswitching effect at all, but this seems an overstatement (see e.g., the evidence surveyed in Paul Krugman [1991]).

Therefore, although flexible exchange rates have indeed proved far more volatile than Friedman envisioned, the flip side of the coin is also a surprise. The effects of the volatility are not as conspicuously disastrous as one might have guessed. So what's the catch, and how should it affect our thinking about exchange-rate regimes?

\section{Goods Markets Are Less Integrated than One Might Imagine}

Obstfeld and Rogoff (2000b) argue that a broad variety of puzzles related to international capital markets can be substantially resolved if one incorporates (significant but plausible) costs of trading goods into canonical models of international trade. (Trade costs include not only tariffs and transport costs, but also costs related to differences in language, legal systems, and yes, possibly currencies). The puzzles include the Feldstein-Horioka puzzle (current accounts tend to be small relative to saving and investment), the home-bias-in-equities puzzle, the international-consumption-correlations puzzle (comovements in national consumptions are not as large as one would expect with significant global capital-market integration), and other puzzles including the purchasing-power-parity puzzle and the exchange-rate disconnect puzzle. Incorporating trade costs not only allows one to resolve most of the major empirical puzzles in international macroeconomics at a qualitative level, but simple calculations suggest that the puzzles can be (substantially) explained at a quantitative level as well. Obstfeld and Rogoff (2000b) do not deny the importance of frictions in capital markets, which they take to be at least

\footnotetext{
${ }^{2}$ See, for example, Jeffrey Frankel and Shang-Jin Wei (1993) or Linda Goldberg and Michael Klein (1998), though their developing-country results do not necessarily extrapolate to OECD countries. Indeed, the strongest case for stabilizing major currency exchange rates may well rest on the way in which their volatility impacts developing countries.
}

as large internationally as domestically. But, they argue, one need not rely on any large difference between domestic and international capital-market frictions to explain many apparent puzzles concerning why capital-market integration is significantly less than one would imagine.

The way in which trade frictions can help explain the exchange-rate disconnect puzzle is straightforward. If the share of traded goods is relatively small (or, to be precise, if trade costs keep the consumption of traded goods relatively small), then the exchange rate (the terms of trade) will likely play a relatively small role in the economy. Correspondingly, very large exchange-rate movements may be required before there is a significant effect on the overall economy. Obstfeld and Rogoff (2000c) illustrate how a sudden reversal of the United States' 4.3-percent (of GDP) year-2000 currentaccount deficit could lead to an extremely sharp depreciation of the dollar exchange rate.

\section{Implications For Exchange-Rate Regimes}

Most critics of the current exchange-rate system accept the point that, under fixed rates (or a common currency), countries would lose their ability to pursue independent monetary policy, and that this loss would be significant. The exact cost depends on a variety of factors, most conspicuously the correlation of macroeconomic conditions across regions. If trade between two large regions is relatively small, and if trade costs also limit capital-market interactions (as Obstfeld and Rogoff [2000b] contend), then standard models imply that it makes little sense to choose the exchange rate as the fundamental target of monetary policy.

Advocates of greater exchange-rate stability across the major currencies argue that standard theoretical and empirical analyses of the efficacy of exchange-rate stabilization are misguided, because they typically assume rational exchange markets. Even if some degree of exchange-rate flexibility across two regions is desirable (say, to accommodate required movements in the real exchange rate due to imperfect output correlation), in reality the exchange rate fluctuates far more than any plausible theory would dictate. Thus a system of fixed exchange rates (or currency unification) is still preferable to any likely scenario under flexible rates. 
The argument I have just presented is robust to this objection. First, with a high degree of goods-market segmentation, small changes in the fundamentals can easily lead to large (fully rational) changes in exchange rates (as Obstfeld and Rogoff [2000c] illustrate). Second, even if a significant share of exchange-rate fluctuations is indeed driven purely by, say, investor psychology, the feedback to the real economy may not be so great as world-currency advocates maintain. Thus, the mere fact that exchange rates between the yen, the euro, and the dollar fluctuate wildly does not provide a prima facie case that we should permanently fix them.

Now, clearly, if moving to a currency union eliminates a substantial bulk of the costs that limit goods- and capital-market integration, suddenly the efficacy of the common currency would be self-fulfilling. However, I am skeptical that this would be the case, notwithstanding the interesting evidence Andrew Rose (2000) provides on the currency arrangements of ministates. It is true that the common currency may ultimately coincide with much higher trade within Europe, but attributing the rise singularly to the adoption of a common currency would seem naive. In fact, at the same time countries in Europe have been pursuing a commoncurrency arrangement, they have taken numerous other steps toward economic integration, ranging from coordination of electric-plug sizes to standardization of supervision and regulation of banks and financial intermediaries. There is a good analogy in the old fable of nail soup: A beggar, trying to talk his way in out of the cold, claims that he can make a most delicious soup with only a nail. The farmer lets him in, and the beggar stirs the soup, saying how good it will taste, but how it would be even better if he could add a leek. After similarly convincing his host to contribute a chicken and all sorts of other good things, the beggar pulls out the magic nail, and indeed, the soup is delicious. The euro is the nail.

\section{Other Reasons To Be Cautious About Adopting a Single World Currency}

There are other reasons that it may not be desirable to pursue currency consolidation all the way to a single world currency: (i) Absent a global government, it would be difficult to establish adequate checks and balances on a global central bank. The U.S. Federal Reserve is technically independent, but it is also fundamentally a creature of Congress, one that could in principle be dissolved at short notice. Although the nascent government institutions of the European Community are still fairly weak, they nevertheless provide some forum for supervision of the European Central Bank. Into the foreseeable future, no parallel institution is going to exist at the global level.

(ii) More generally, political problems could make it difficult to choose top-notch central bankers and, equally importantly, conservative central bankers who place a strong weight on inflation. In principle, one can design mechanical rules (such as inflation targets) which reduce the importance of the individuals governing the central bank. In many developing countries, this second-best approach may indeed be far preferable to a random draw from the political process, but I am very skeptical of claims that any simple mechanical rule can come close to what can be achieved by a grandmaster of monetary policy such as Alan Greenspan. This is indeed a common finding in the artificial-intelligence literature; that is, computers can equal "expert" level in many fields but not "master" level.

(iii) Though currency, particularly in its function as a unit of account, is a natural monopoly, there are several reasons why it may be desirable to maintain some level of competition. Through a number of channels, global currency competition provides a check on inflation (as illustrated, for example, in Rogoff [1985]). A related concern comes from the natural regulatory functions that a global central bank (or a sister agency) would have to assume. In an era of ongoing financial innovation, in which paper currency may well become defunct, there are ample reasons to be concerned that a global central bank might constrain innovation, either out of the desire to maintain a strong monopoly or simply due to misjudgment. These are also going to be problems in the current system, 
but they would only be exacerbated by having a single currency.

(iv) One could bypass many of the objections I have raised by adopting a world currency pegged to a commodity basket (or just, say, to gold). However, I believe that the invention of the modern central bank, on the whole, has actually been a very good one, and certainly not worth abandoning for the uncertain gains of global currency unification.

\section{Why Not a Lessor Level of Coordination among the Big Three (Euro, Dollar, and Yen)?}

Even if an optimal system requires some degree of monetary response to exchange rates, there is a case to be made that the current system already works reasonably well. Obstfeld and Rogoff (2000d) show that when monetary policy is governed by a rule-based environment (i.e., if standard time consistency in monetary policy problems can be overcome), then the gains to international monetary cooperation are not necessarily very large. While in principle countries may be tempted to tilt their rules in a way that improves their individual terms of trade (via the effects of risk on wage- and pricesetting) or that provides a more favorable correlation between consumption and the exchange rate, theory suggests good reasons to believe that these gains are likely to be only secondorder. Loosely speaking, improvements in the terms of trade come only at the expense of less effective risk-sharing. In empirical simulations, Obstfeld and Rogoff (2000d) find that the gains to having an optimal global exchange-rate system (over the noncooperative equilibrium) are two orders of magnitude less than the gains from following active versus passive monetary stabilization policy. Interestingly, the argument here does not depend at all on having sizable trade costs, and indeed the need for global coordination in rule-setting is weakest at the extremes where either all goods are traded or no goods are traded. Of course, one can argue that some of the world's major central banks (notably the European Central Bank and the Bank of Japan) have not yet fully converged to a rulebased equilibrium, in which case there is still scope for coordination in the transition.

\section{Conclusions}

Currency consolidation seems like a desirable and (at present) likely process; but it is already important to begin thinking about where consolidation should stop. I have argued here that, into the foreseeable future, it would not be desirable to aim for a single world currency, and that from an economic point of view, it would be preferable to retain at least, say, three or four currencies, if not $n$ currencies.

\section{REFERENCES}

-Baxter, Marianne and Stockman, Alan. "Business Cycles and the Exchange Rate Regime: Some International Evidence." Journal of Monetary Economics, May 1989, 23(3), pp. 377-400.

Clarida, Richard. "G-3 Exchange Rate Relationships: A Review of the Record and Proposals for Change." Princeton Essays in International Economics No. 219, Princeton University, September 2000.

-Cooper, Richard. "A Monetary System for the Future.” Foreign Affairs, Fall 1984, 63(1), pp. 166-84.

Frankel, Jeffrey and Wei, Shang-Jin. "Trade Blocks and Currency Blocks," in Guillermo de la Dehaza, Alberto Giovannini, Manuel Guitian, and Richard Portes, eds., The monetary future of Europe. London: Centre for Economic Policy Research, 1993, pp. $1-52$.

Friedman, Milton. "The Case for Flexible Exchange Rates," in Milton Friedman, Essays in positive economics. Chicago: University of Chicago Press, 1953, pp. 157-203.

Goldberg, Linda and Klein, Michael. "Foreign Direct Investment, Trade and Real Exchange Rate Linkages in Developing Countries," in Reuven Glick, ed., Managing capital flows and exchange rates. Cambridge: Cambridge University Press, 1998, pp. 73-100.

Krugman, Paul. "Has the Adjustment Process Worked?" in C. Fred Bergsten, ed., International adjustment and financing: The lessons of 1985-1991. Washington, DC: Institute for International Economics, 1991, pp. 277-322.

McKinnon, Ronald. An international standard for monetary stabilization. Washington, DC: Institute for International Economics, 1984. 
-Obstfeld, Maurice and Rogoff, Kenneth. "New Directions for Stochastic Open Economy Models." Journal of International Economics, February 2000a, 50(1), pp. 117-53. . "The Six Major Puzzles in International Macroeconomics: Is there a Common Cause?" in Ben Bernanke and Kenneth Rogoff, eds., NBER Macroeconomics Annual 2000. Cambridge, MA: MIT Press, 2000b, pp. 339-90.

- "Perspectives on OECD Capital Market Integration: Implications for U.S. Current Account Adjustment," in Global economic integration. Kansas City, MO: Federal Reserve Bank of Kansas City, 2000c, pp. 169208.
" "Do We Really Need a New International Monetary Compact?" National Bureau of Economic Research (Cambridge, MA) Working Paper No. 7864, August 2000d.

- Rogoff, Kenneth. "Can International Monetary Policy be Counterproductive?" Journal of International Economics, May 1985, 18(3/4), pp. 199-217.

-Rose, Andrew K. "One Money, One Market: The Effect of Common Currencies on Trade." Economic Policy: A European Forum, April 2000, (30), pp. 7-33.

-Williamson, John. "Exchange Rate Management." Economic Journal, January 1993, 103(416), pp. 188-97. 


\section{This article has been cited by:}

1. Robin Pope, Reinhard Selten, Johannes Kaiser, Sebastian Kube, Jürgen Hagen. 2012. Exchange rate determination: a theory of the decisive role of central bank cooperation and conflict. International Economics and Economic Policy . [CrossRef]

2. Grahame Thompson. 2010. 'Financial Globalisation' and the 'Crisis': A Critical Assessment and 'What is to be Done'?. New Political Economy 15:1, 127-145. [CrossRef]

3. Jean-François Ponsot, Louis-Philippe Rochon. 2009. South America and a new financial architecture. Journal of Post Keynesian Economics 32:2, 155-162. [CrossRef]

4. Hiroya Akiba, Yukihiro Iida. 2009. Monetary Unions and Endogeneity of the OCA Criteria. Global Economic Review 38:1, 101-116. [CrossRef]

5. Stephen G. Hall, George Hondroyiannis. 2007. Measuring the correlation of shocks between the EU15 and the new member countries. Economic Change and Restructuring 39:1-2, 19-34. [CrossRef]

6. Sergio L. Schmukler. 2006. Comments on R. Cooper, M. Bordo and H. James: Exchange rate arrangements and disarrangements: prospects for a world currency. International Economics and Economic Policy 3:3-4, 409-414. [CrossRef]

7. Stephen G. HallModelling Volatility and Its Implication for European Economic Integration 269, 1-19. [CrossRef]

8. George M. von Furstenberg, Jianjun Wei. 2004. Overcoming Chinese Monetary Division and External Anchoring in East Asia*. Asian Economic Papers 3:1, 27-54. [CrossRef]

9. M.J. Artis. 2003. Reflections on the optimal currency area (OCA) criteria in the light of EMU. International Journal of Finance \& Economics 8:4, 297-307. [CrossRef] 